Myronyuk 0., Baklan D., Nudchenko L.

\title{
EVALUATION OF THE SURFACE ENERGY OF DISPERSED ALUMINIUM OXIDE USING OWENS-WENDT THEORY
}

Знання значення поверхневої енергї порошкових матеріалів дозволяє спрогнозувати взаємодію твердої фази з рідинами, формування стійких дисперсій, довговічних і стійких до агресивних факторів композитів. Розглядається застосування моделі Оуенса-Вендта для визначення зміни поверхневої енергї оксиду алюмінію, модифікованого різними гідрофобізаторами. Також, для визначення кута змочування поверхні модифікованого матеріалу використовується метод Уошбурна, який полягає у визначенні швидкості капілярного підняття випробуваної рідини. Даний метод був обраний через низькі вимоги в точності вимірювального обладнання і в той же час проявляє високу ступінь точності результатів.

Об'єктом дослідження є методика визначення поверхневої енергї порошкових матеріалів, на прикладi оксиду алюмінію модифікованого поліметілгідрідсілоксаном. Модифікація поверхні порошку оксиду алюмінію проводилася в суспензї ксилолу.

В роботі визначення поверхневої енергії було проведено відповідно до теорії Оуенса-Вендта графічним методом відповідно до отриманих значень кута змочування матеріалу за методом Уошбурна. Було встановлено форму частинок оксиду алюмінію та іх середній розмір, а також розрахована питома поверхня матеріалу. Знайдено модифікатор - поліметілгідрідсілоксан, з використанням якого вдалося отримати стабільний супергідрофобний стан, і оптимальну концентрацію шляхом визначення кутів змочування тестовими рідинами порошкового матеріалу за методикою, запропонованою Уошбурном.

Для збільшення точності визначення поверхневої енергї матеріалу за методом Уошбурна була застосована суміш води з етанолом, а також розраховані компоненти поверхневого натягу. Показано, що значення кута змочування поверхні дисперсного матеріалу, отримані з використанням в якості тестової рідини суміш, можуть бути використані для розрахунку значень компонентів поверхневої енергї оксиду алюмінію. При цьому спостерігається відсутність похибки у вигляді стану Кассі, яке спостерігається для гідрофобних дисперсних матеріалів при використанні води в якості тестової рідини.

Ключові слова: оксид алюмінію, модель Оуенса-Вендта, метод Уошбурна, поверхнева енергія, поверхневий натяг.

Received date: 23.01 .2020

Accepted date: 28.02 .2020

Published date: 30.04 .2020
Copyright (C) 2020, Myronyuk O., Baklan D., Nudchenko L. This is an open access article under the CC BY license (http://creativecommons.org/licenses/by/4.0)

\section{Introduction}

Knowledge of the surface energy of powder materials allows one to predict the interaction of the solid phase with liquids, the formation of stable dispersions, durable and resistant to aggressive factors of composites [1]. Existing models of surface energy - from Zisman (one-component) to Van Oss (three-component), are suitable only for certain types of materials [2, 3]. For example, to characterize the surface of oxides, a model involving an acid-base interaction is used, and for polar polymers, the Owens-Wendt model. The paper considers the application of the latter model to determine changes in the surface energy of aluminium oxide modified by various water repellents. Also, the Washburn method [4,5] is used to determine the contact angle of the surface of the modified material [4, 5], which consists in determining the rate of capillary rise of the test fluid. Of the two methods for implementing this method - determining the mass gain rate and the layer climb speed - the second one is chosen, since it does not require such accurate measuring equipment, but it exhibits a rather high degree of accuracy of the results [6-8]. Thus, the object of research is a method for determining the surface energy of powder materials, for example, aluminium oxide modified with polymethylhydrosiloxane. The aim of research is to describe a simple algorithm for determining the surface energy of powder materials.

\section{Methods of research}

The studies were carried out using white aluminium oxide 25A/M2 (GOST 3647-71) (Boksitogorsk plant of the «Glinozem» production association, Russia), which is aluminium oxide with a density of $3.93-4.1 \mathrm{~g} / \mathrm{cm}^{3}$ and an average particle size of $2 \mu \mathrm{m}$.

The following modifiers were used: a mixture of cyclopentasiloxane and dimethicone BC 2335 (KCC Basildon, Great Britain), methyltriethoxysilane Dynasylan MTES (Evonic, Germany), aminopropyltriethoxysilane Dynasylan AMEO (Evonic, Germany) and polymethylhydrosiloxane Xiameter MHX 1107 (Dow Corning, USA). Xylene was used as a solvent for silanes. 
To modify the surface of the powder into a suspension of aluminium oxide in xylene, the required amount of modifier was dosed: $0.05 ; 0.07$; $0.1 ; 0.3$ and 0.5 mass \%. The prepared samples were dried on the surface of the watch glass for 24 hours without heating.

To determine the contact angle of prepared samples with test liquids, the Washburn thinwalled capillary impregnation technique was used. Samples were prepared in the form of a $5 \%$ suspension in isopropyl alcohol and applied to the glass surface with dimensions of $4 \times 8 \mathrm{~mm}$. After drying the suspensions, markings were applied on the surface of the layer (three consecutive marks with a distance of $1 \mathrm{~mm}$ ). Samples were conditioned in vapors of the test fluid and then measured the passage time between the marks of the wetting front during immersion.

The wetting time was recorded using a video camera with an accuracy of $0.1 \mathrm{~s}$. The number of time measurements for each solvent was 5 times, and the average measurement error in the entire array of solvents was $6.9 \%$. For calculations, the modified Washburn equation (1) was used, assuming that the most non-polar liquid - hexane completely wets the surface, i. e. the cosine of the contact angle approaches unity.

$$
\cos \theta=\frac{\mu_{t} \cdot \sigma_{0}}{\mu_{0} \cdot \sigma_{t}} \cdot \frac{t_{0}}{t_{t}}
$$

where $\mu$ - the dynamic viscosity of the liquid; $\sigma$ - its surface tension; $t$ - the travel time of the front between the marks; index 0 corresponds to hexane, index $t$ corresponds to test fluid.

The surface energy was determined in accordance with the Owens-Wendt theory by the graphical method in accordance with the values obtained by the Washburn method for the contact angle of the material with test liquids $[9,10]$.

\section{Research results and discussion}

It is established that the particles of aluminium oxide have an irregular, fragmentation shape (Fig. 1). The closest geometric figure is a prism. The average particle size is $3.3 \mu \mathrm{m}$, while the distribution of their sizes (Fig. 2, $a, b$ ) is monomodal and quite narrow - with a minimum particle size of $1.6 \mu \mathrm{m}$ and a maximum of $6.3 \mu \mathrm{m}$. The calculated specific surface area of the material, provided there is no capillary porosity of the particles, is $2800 \mathrm{~cm}^{2} / \mathrm{g}$.

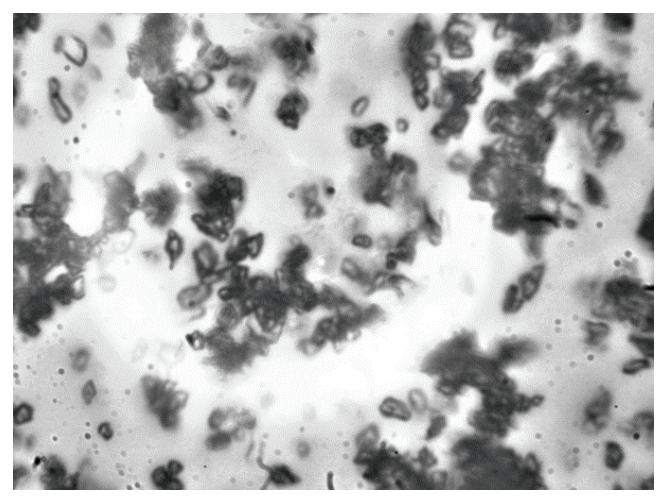

Fig. 1. Optical microscopy of aluminium oxide particles

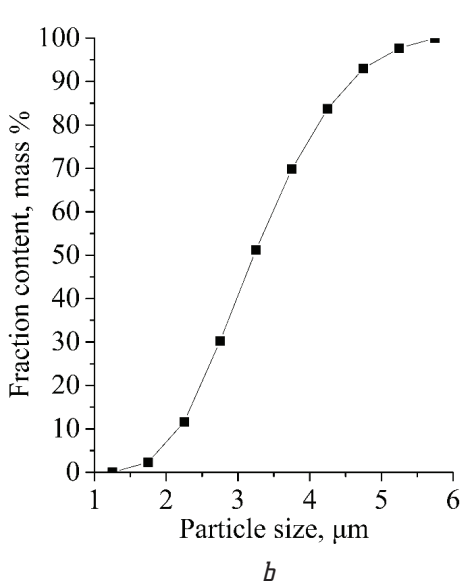

Fig. 2. Particle size distribution: $a$ - differential curve; $b$ - integral curve

Of all the surface modifiers tested, provided that they were dried under atmospheric conditions, only Xiameter MHX 1107 allows to obtain a stable superhydrophobic state, which is characterized by the rolling of drops of distilled water from the surface of the powder sample at the end of processing. This state is observed for modifier concentrations equal to and above 0.1 mass \% by weight of aluminium oxide and, probably, is a consequence of a decrease in the polar component of surface energy. This assumption is verified by determining the contact angles of the powder material with test liquids according to the method proposed by Washburn, and hexane is used as test liquid. ethanol and distilled water, as well as a mixture of the last two solvents.

Graph in Fig. 3 is a combination of the measurement results by the Washburn method (up to a modifier concentration of 0.1 mass \%) with the results of measuring the contact angle by the sitting drop method (0.1 mass \% and higher).

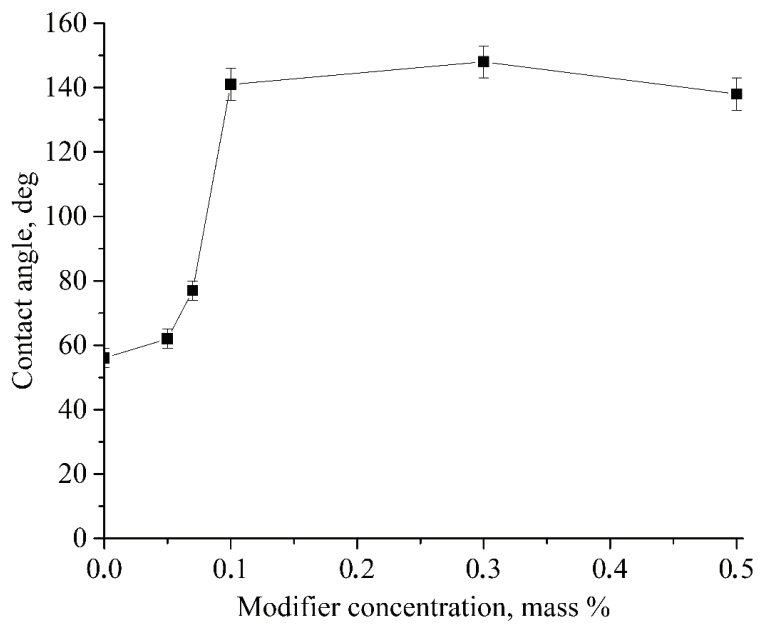

Fig. 3. Change the contact angle of the aluminium axide surface

Noteworthy is the sharp jump in the contact angle in the concentration range of polymethylhydrosiloxane from 0.07 to 0.1 mass \%. However, it is likely that when using water as a test fluid in the sitting drop method, a Cassie state is achieved. This introduces a certain error in the measurements and does not allow to accurately determine the surface energy of the material. 
To solve this problem in the Washburn method, water as a test fluid is replaced with its mixture with ethanol. The components of the surface tension of the mixture were calculated in accordance with the procedure [11].

Fig. 4 shows that the change in the dispersion and polar components of the energy of the surface of aluminium oxide with increasing concentration of the modifier most pronounced occurs in the range from 0.05 to 0.1 mass \%. A significant decrease in the polar component is associated with the screening of the active functional groups of the oxide surface by a nonpolar modifier [12].

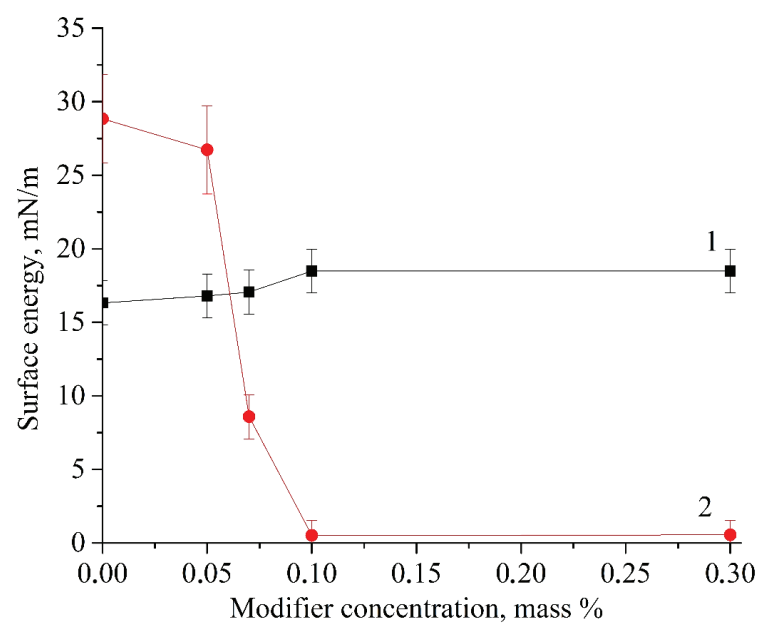

Fig. 4. The dependence of the $\mathrm{Al}_{2} \mathrm{O}_{3}$ surface energy components depending on the concentration of polymethylhydrosiloxane: 1 - dispersed; 2 - polar

It is worth noting that for cases of hydrophobic material it is possible to choose a mixture of ethanol and water, the surface contact angle of which will be 90 degrees. In this case, the ordinate of the solvent point in the OwensWendt graphical method takes the minimum value:

$$
y=\frac{\sigma_{L}}{2 \sqrt{\sigma_{L}^{D}}}
$$

where $\sigma_{L}$ - the surface tension of the test fluid, and $\sigma_{L}^{D}-$ the dispersion component of its surface tension.

\section{Conclusions}

It is established that the white aluminium oxide used in the work has a monomodal distribution of particles, the average size of which is $3.3 \mu \mathrm{m}$. The most effective modifier for the surface of this material is Xiameter MHX 1107 polymethylhydrosiloxane.

It is shown that the contact angle of the surface of the dispersed material obtained by the Washburn method using a mixed solvent (water-ethanol) as a test fluid can be used to calculate the values of the surface energy components of aluminium oxide. There is no error in the form of the Cassie state, which is observed for hydrophobic dispersed materials when using water as a test fluid.

The value of the effective concentration of the modifier, which is 0.1 mass \% by weight of the dispersed material. Moreover, a sharp drop in the share of the polar component of its surface energy occurs, starting from 0.05 mass \% modifier.

\section{References}

1. Chibowski, E., Holysz, L., Szczes, A. (2017). Wettability of Powders. Adhesion in Pharmaceutical, Biomedical and Dental Fields, 23-49. doi: http://doi.org/10.1002/9781119323716.ch2

2. Zisman, W. A. (1964). Relation of the Equilibrium Contact Angle to Liquid and Solid Constitution. Contact Angle, Wettability, and Adhesion, 1-51. doi: http://doi.org/10.1021/ ba-1964-0043.ch001

3. Good, R. J., van Oss, C. J. (1992). The Modern Theory of Contact Angles and the Hydrogen Bond Components of Surface Energies. Modern Approaches to Wettability, 1-27. doi: http:// doi.org/10.1007/978-1-4899-1176-6_1

4. Chibowski, E., Holysz, L. (1992). Use of the Washburn equation for surface free energy determination. Langmuir, 8 (2), 710-716. doi: http://doi.org/10.1021/la00038a066

5. Trong, D. V., Hupka, J. (2005). Characterization of porous materials by capillary rise method. Physicochemical Problems of Mineral Processing, 39, 47-65.

6. Zhang, D., Luo, R. (2017). Development of a method to determine surface energy components of mineral fillers. Construction and Building Materials, 146, 370-380. doi: http:// doi.org/10.1016/j.conbuildmat.2017.04.071

7. Zhang, D., Luo, R. (2019). A novel method for measuring surface free energy of highly wettable mineral powders. Construction and Building Materials, 229, 116915. doi: http://doi.org/ 10.1016/j.conbuildmat.2019.116915

8. Zhang, D., Luo, R. (2020). An alternative method to evaluate the surface free energy of mineral fillers based on the generalized Washburn equation. Construction and Building Materials, 231, 117164. doi: http://doi.org/10.1016/j.conbuildmat.2019.117164

9. Annamalai, M., Gopinadhan, K., Han, S. A., Saha, S., Park, H. J., Cho, E. B. et. al. (2016). Surface energy and wettability of van der Waals structures. Nanoscale, 8 (10), 5764-5770. doi: http:// doi.org/10.1039/c5nr06705g

10. Myronyuk, O., Prydatko, A., Sivolapov, P., Svidersky, V. (2017). Aspects of polymer surfaces wetting. Eastern-European Journal of Enterprise Technologies, 6 (67), 23-26. doi: http://doi.org/ 10.15587/1729-4061.2014.20797

11. Zhang, Z., Wang, W., Korpacz, A. N., Dufour, C. R., Weiland, Z. J., Lambert, C. R., Timko, M. T. (2019). Binary Liquid Mixture Contact-Angle Measurements for Precise Estimation of Surface Free Energy. Langmuir, 35 (38), 12317-12325. doi: http://doi.org/ 10.1021/acs.langmuir.9b01252

12. Prado, L. A. S. A., Sriyai, M., Ghislandi, M., Barros-Timmons, A., Schulte, K. (2010). Surface modification of alumina nanoparticles with silane coupling agents. Journal of the Brazilian Chemical Society, 21 (12), 2238-2245. doi: http://doi.org/10.1590/ s0103-50532010001200010

Myronyuk Oleksiy, PhD, Associate Professor, Department of Chemical Technology of Composition Materials, National Technical University of Ukraine «Igor Sikorsky Kyiv Polytechnic Institute», Ukraine, e-mail: whizershines@gmail.com, ORCID: http://orcid.org/ 0000-0003-0499-9491

Baklan Denys, Postgraduate Student, Department of Chemical Technology of Composition Materials, National Technical University of Ukraine «Igor Sikorsky Kyiv Polytechnic Institute», Ukraine, e-mail:denisbaklan1kpi@gmail.com,ORCID: http://orcid.org/00000002-6608-0117

Nudchenko Lyudmyla, Senior Lecturer, Department of Chemical Technology of Composition Materials, National Technical University of Ukraine «Igor Sikorsky Kyiv Polytechnic Institute», Ukraine, e-mail:xtkm@kpi.ua,ORCID:http://orcid.org/0000-0001-6519-9864 